\title{
Transducin Beta-Like Protein 2
}

National Cancer Institute

\section{Source}

National Cancer Institute. Transducin Beta-Like Protein 2. NCI Thesaurus. Code C104553.

Transducin beta-like protein 2 (447 aa, $\sim 50 \mathrm{kDa}$ ) is encoded by the human TBL2 gene. This protein may be involved in signal transduction. 